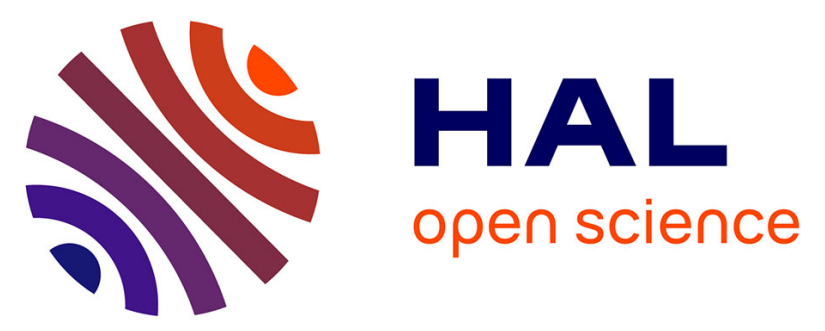

\title{
Biochemical and histological alterations of cellular metabolism from jerboa (Jaculus orientalis) by 2,4-dichlorophenoxyacetic acid: Effects on D-3-hydroxybutyrate dehydrogenase
}

Driss Mountassif, Mostafa Kabine, Karima Mounchid, Khadija Mounaji, Norbert Latruffe, M'Hammed Saïd El Kebbaj

\section{To cite this version:}

Driss Mountassif, Mostafa Kabine, Karima Mounchid, Khadija Mounaji, Norbert Latruffe, et al.. Biochemical and histological alterations of cellular metabolism from jerboa (Jaculus orientalis) by 2,4dichlorophenoxyacetic acid: Effects on D-3-hydroxybutyrate dehydrogenase. Pesticide Biochemistry and Physiology, 2007, pp.10. hal-00376293

\section{HAL Id: hal-00376293 https://hal.science/hal-00376293}

Submitted on 17 Apr 2009

HAL is a multi-disciplinary open access archive for the deposit and dissemination of scientific research documents, whether they are published or not. The documents may come from teaching and research institutions in France or abroad, or from public or private research centers.
L'archive ouverte pluridisciplinaire HAL, est destinée au dépôt et à la diffusion de documents scientifiques de niveau recherche, publiés ou non, émanant des établissements d'enseignement et de recherche français ou étrangers, des laboratoires publics ou privés. 


\section{Biochemical and Histological alterations of cellular metabolism from jerboa (Jaculus orientalis) by 2, 4-Dichlorophenoxyacetic acid: Effects on D-3-hydroxybutyrate dehydrogenase}

Driss Mountassif ${ }^{1}$, Mostafa Kabine ${ }^{1}$, Karima Mounchid ${ }^{2}$, Khadija Mounaji ${ }^{3}$, Norbert Latruffe ${ }^{4}$ and M'Hammed Saïd El Kebbaj ${ }^{1}$

${ }^{1}$ Laboratoire de Biochimie et Biologie Moléculaire, Université Hassan II - Aïn Chock, Faculté des Sciences, km 8 route d'El Jadida BP. 5366, Casablanca, Morocco.

${ }^{2}$ Laboratoire d'Histologie et Embryologie, Université Hassan II - Aïn Chock, Faculté de Médecine et Pharmacie, Casablanca, Morocco.

${ }^{3}$ Laboratoire de Physiologie et Génétique Moléculaire, Université Hassan II - Aïn Chock, Faculté des Sciences, Casablanca, Morocco.

4 INSERM U 866; Université de Bourgogne, Laboratoire de Biochimie Métabolique et Nutritionnelle, Faculté des Sciences, 6 Bd Gabriel, 21000 Dijon cedex, France.

To whom correspondence may be addressed:

* Corresponding author (Tel. + (212) 222306 80/84; Fax: + (212) 222306 74; E-mail address: drissmountassif@yahoo.fr) 


\section{Abstract:}

2, 4-Dichlorophenoxyacetic acid (2,4D) is one of the widely used herbicide of the phenoxy family with possible startling number of adverse effects on species other than the weeds which it is designed to kill. The effects of 2,4D were investigated in jerboa (Jaculus orientalis), a wild animal of sub-desert highlands. The Jerboas have been daily treated intraperitonally with $3 \mathrm{mg} / \mathrm{kg}$ body weight for 4 weeks. Plasmatic markers, and antioxidants defences systems were assessed and histological alterations were evaluated. The in vivo and in vitro effects of 2,4D on the mitochondrial D-3-hydroxybutyrate dehydrogenase $(\mathrm{BDH})$ were also determined. Our results showed a strong decrease of triglycerides level and HDL cholesterol and an increase in GOT level and LDL cholesterol. The microscopic evaluation showed that 2,4D induced necrosis of seminiferous tubules cells in testis, hyperplasia of hepatocytes in liver and presence of multinucleated giant cells in brain. The results show also an inhibitory effect on BDH in terms of activity and kinetic parameters. All of these results show that 2,4D induces toxicity which affect energy metabolism, morphological perturbation and oxidative stress.

Key words: 2,4D, Jaculus orientalis, clinical parameters, antioxidant enzymes, subcellular markers, histology, D-3-hydroxybutyrate dehydrogenase.

\section{Abbreviations:}

BDH, D-3-Hydroxybutyrate dehydrogenase; CPK, Creatine phosphokinase; DL-BOH, DL-3hydroxybutyrate ; DCIP, Dichloroindophenol; 2,4D, 2,4-Dichlorophenoxyacetic acid; EDTA, Ethylenediamine tetraacetic acid; D-G-3-P, D-Glycerol-3-phosphate; GOT, Glutamate Oxalate Transaminase; GPT, Glutamate Pyruvate Transaminase; HDL, High Density Lipoprotein; KCN, Potassium cyanide; NAD(H), LDL, Low Density Lipoprotein; Nicotinamide Adenine Dinucleotide Oxidized (reduced) forms; NADPH, Nicotinamide Adenine Dinucleotide Phosphate reduced form. 


\section{Introduction:}

Pesticides of worldwide application are used in agriculture in vast amounts each year, of which herbicides are the most prominent class. Phenoxyacetic herbicides constitute one of the largest groups of herbicides sold in the world. Among them, for many years 2, 4-dichlorophenoxyacetic acid (2,4D) has been the one most used (Zeljezic and Garaj-Vrhovac, 2004). 2,4D is a plant growth inhibitor. It is absorbed into a plant through the plant's surface. This weed killer circulates through all parts of the plant causing abnormal growth by blockage of the passage of medium and nutrients. Subsequently, the roots starve and the plant dies.

2,4D is a moderately persistent chemical with a half-life between 20 and 200 days (Associate Committee on Scientific Criteria for Environmental Quality, 1994). Unfortunately, this herbicide is no a specific weeds target. It can cause low growth rates, reproductive problems, changes in appearance or behavior, or death in non-target species, including plants, animals and microorganisms.

Additionally, the spraying of 2,4D often contaminates ground water systems. About $91.7 \%$ of $2,4 \mathrm{D}$ will eventually end up in water (Associate committee on Scientific Criteria for Environmental Quality, 1994). This contamination threatens the vegetation and the animal life that are exposed. The chemical will also be carried by run-off into the local river systems, thereby jeopardizing the health of aquatic life as well.

In the urban setting, it has been proven that households using 2,4D put their dogs at twice the risk of developing canine malignant lymphoma (Hayes and Howard, 1991). Documented health problems related to 2,4D include reproductive damage (i.e. sterility), respiratory difficulties, atrophy, nausea, loss of appetite, skin rashes, eye irritation and chronic headaches. Non-Hodgkin's lymphoma has also been associated with 2,4D exposure (Kogevinas, 1995). Furthermore, there is evidence of teratogenicity (birth defects) and mutagenicity provided by studies involving 2,4D and lab animals. Workers applying chlorinated phenoxy herbicides frequently have nervous system disorders, are 
exposed to a higher risk of soft tissue sarcoma, and show symptoms of hormonal and internal organ irregularities (Hayes and Howard, 1991).

A wide number of environmental pollutants exert their toxic action by interfering at different levels with mitochondrial respiration, a fundamental step of energy metabolism in eukaryotic organisms. Mitochondria have been recognized as subcellular targets of many xenobiotic compounds; as a consequence, toxicity endpoints related to respiratory functions have been widely used in recent years to assess the adverse effects of various toxicants and to investigate the mechanisms of their action by means of suitable in vitro systems (Argese et al., 2005).

To approach these questions, we used as model system the mitochondrial inner membrane bound NAD-dependent D-3 -hydroxybutyrate dehydrogenase (BDH, EC. 1.1.1.30) which play a essential role in the redox balance. Any alteration of its activity will affect the energetic metabolism. In liver, the enzyme catalyses the conversion of acetoacetate into D-3-hydroxybutyrate in the presence of NADH. This reduced substrate is then transported through the blood stream to peripheral organs, i.e. brain, heart, kidney...(Williamson et al., 1971). In such extrahepatic tissues, D-3-hydroxybutyrate is converted into acetoacetate in the presence of NAD + . This substrate is then used, after its conversion to acetyl-CoA, by the respiratory chain as fuel for ATP production, or after formation of acetoacetylCoA, for fatty acid synthesis. A catalytic mechanism of the interconversion of D-3-hydroxybutyrate and acetoacetate in both liver and peripheral tissues has been previously proposed by our group (El Kebbaj et al., 1997). Moreover this enzyme from Jerboa has been extensively studied in our lab (Kante et al. 1990, El Kebbaj et al., 1995; Mountassif et al., 2006).

The jerboa (Jaculus orientalis), a nocturnal herbivorous rodent living in the subdesert highland of Morocco is an appropriate organism to study metabolic regulation due to its remarkable tolerance to heat, dry diet and cold. Also, it is one of the small mammals that can undergo hibernation (Hooper and El Hilali, 1972; El Hilali and Veillat, 1979). Some studies also demonstrated the originality of jerboa in the study of peroxisome proliferator-activated receptor (PPAR) (Amsaguine-Safir et al., 2003 and Kabine et al., 2004). Indeed, El Kebbaj et al. (1996), utilizing a different type of rodent 
(rat, guinea pig and jerboa), reveal that the jerboa shows unique peroxisome properties and responds in a moderate manner to a peroxisome proliferator such as ciprofibrate, without leading to any increase in liver mass or hepatomegaly in contrast to rat, guinea pig and human.

On the other hand, beside numerous species previously used for testing agrochemical pollutants sensitivity, here, for the first time, we report a study on jerboa as a new model for evaluation of 2,4D toxicity. Indeed, jerboa is a wild animal which can be maintained at the laboratory in order to test such environmental chemicals.

The purpose of this study was to provide the impact of 2,4D on the cellular antioxidants, metabolic pathways, cells histology and their effects on the D-3-hydroxybutyrate dehydrogenase activity, protein level and kinetic parameters in mitochondria.

Répondre à la question du referee

"It is not clear if this work was done with an emphasis upon effects and biomarkers for wildlife exposure or for humans." 


\section{Materials and Methods:}

\subsection{Chemicals:}

2, 4-Dichlorophenoxyacetic Acid, Succinate and Cytochrome C were from Sigma (St Louis, USA); DL-3-hydroxybutyrate (sodium salt) was purchased from Fluka (Buchs Switzerland); NAD+ (free acid) and NADH were from Boehringer (Mannheim, Germany) and all other chemicals were of analytical grade.

\subsection{Animal and administration of 2,4D:}

Adult jerboas (120 - 150 g), 4-6 months, were captured in the area of Engil Aït Lahcen (in subdesert East Moroccan highland). They were adapted to laboratory conditions during 3 weeks at a temperature of $22^{\circ} \mathrm{C}$ with food (salad and rat diet), and water ad libitum. The light cycle during the entire experiment was set to 14 hours light and 10 hours dark. The 2,4D was dissolved in $1 \mathrm{ml}$ sterile water and administered daily by intraperitoneal injection for four weeks. Four jerboas were given 2,4D (3 mg/kg/day) while control groups were given sterile water serving as control. All the experiments were done in compliance with the Guide for The Care and Use of Laboratory Animals.

\subsection{Blood analysis:}

The determination of the total cholesterol, HDL, LDL, triglycerides, CPK and transaminases (glutamate oxalate transaminase (GOT) and glutamate pyruvate transaminase (GPT)) was carried out by Centre National de Transfusion Sanguine, Casablanca, using the conventional methods.

\subsection{Liver mitochondria isolation:}

The jerboas were decapitated and the liver and brain were rapidly removed for mitochondrial extraction according to Fleischer et al. (1979). This method allowed the preparation of high yield and pure mitochondria. 


\subsection{Biochemical assays:}

All assays were conducted at $37^{\circ} \mathrm{C}$ using Jenway $6405 \mathrm{UV} /$ Visible spectrophotometer and done with liver homogenate except acetylcholinesterase which was assessed with brain homogenate.

\subsubsection{Catalase:}

The consumption of $7.5 \mathrm{mM} \mathrm{H}_{2} \mathrm{O}_{2}$ in $50 \mathrm{mM}$ potassium phosphate buffer ( $\mathrm{pH}$ 7) was monitored at $240 \mathrm{~nm}$ according to Aebi, 1984.

\subsubsection{Palmitoyl-CoA oxidase:}

The enzyme was assayed according to Lazarow and De Duve (1976) with assay conditions: $50 \mathrm{mM}$ phosphate buffer ( $\mathrm{pH} 7.4$ ), $0.2 \mathrm{mM} \mathrm{NAD}+, 50 \mu \mathrm{M} \mathrm{FAD}+, 12 \mathrm{mM}, 1 \mathrm{mM} \mathrm{KCN}, 200 \mu \mathrm{g}$ of BSA and $100 \mu \mathrm{g}$ of protein. The mixture was preincubated $10 \mathrm{~min}$ at $37^{\circ} \mathrm{C}$ before adding $50 \mu \mathrm{M}$ of palmitoyl$\mathrm{CoA}($ Sigma) as final concentration. The measure of activity was done at $340 \mathrm{~nm}$.

\subsubsection{Glutathione reductase:}

The assay of Di ilio et al. (1983) was used. Assay mixture contained $0.5 \mathrm{mM}$ oxidized glutathione, 1 $\mathrm{mM}$ EDTA, $0.1 \mathrm{mM}$ NADPH and $50 \mathrm{mM}$ potassium phosphate buffer (pH 7.4) and NADPH consumption was monitored at $340 \mathrm{~nm}$.

\subsubsection{Superoxide dismutase:}

The enzyme was assayed according to Paoletti et al. (1986) with assay conditions: 5 mM EDTA, 2.5 $\mathrm{mM} \mathrm{MnCl} 2,0.27 \mathrm{mM}$ NADH, $3.9 \mathrm{mM}$ 2-mercaptoethanol in $50 \mathrm{mM}$ potassium phosphate buffer ( $\mathrm{pH} 7$ ), monitored at $340 \mathrm{~nm}$. The activity was started by the addition of NADH to $0.27 \mathrm{mM}$ final concentration.

\subsubsection{Thiobarbituric acid reactive substances:}

Lipid peroxidation was estimated by the formation of thiobarbituric acid reactive substances (TBARS) and quantified in terms of malondialdehyde (MDA) equivalents according to the method described by Samokyszyn and Marnett (1990). 
One $\mathrm{ml}$ of samples was added to $1 \mathrm{ml}$ solution $(0.375 \%$ thiobarbituric acid and $15 \%$ trichloracetic acid in $0.25 \mathrm{M}$ hydrochloric acid). The tubes were heated at $100^{\circ} \mathrm{C}$ during $15 \mathrm{~min}$. Then, they were cooled in the ice to stop the reaction. One then carried out a centrifugation with $1000 \mathrm{~g}$ during 10 min. The reading of supernatant was made to $535 \mathrm{~nm}$.

\subsubsection{NADPH-cytochrome $C$ reductase:}

NADPH-cytochrome c reductase was measured as described by Williams and Kamin (1962). The reaction mixture contained $50 \mathrm{mM}$ sodium phosphate buffer $(\mathrm{pH} 7.7), 1.25 \mathrm{mg} / \mathrm{ml}$ cytochrome $\mathrm{C}, 0.1$ $\mathrm{mM}$ EDTA and $100 \mu \mathrm{g}$ of protein were incubated during 2 min at $37^{\circ} \mathrm{C}$, then the NADPH at $100 \mu \mathrm{M}$ final concentration was added and the increase in absorbance due to the reduction of cytochrome $\mathrm{C}$ was measured.

\subsubsection{Glycerol 3-phosphate dehydrogenase:}

The enzyme was assayed according to Bentley et al. (1973) with assay conditions: $100 \mathrm{mM}$ glycine $\mathrm{NaOH}$ buffer $(\mathrm{pH} 9), 5 \mathrm{mM} \mathrm{NAD}+$ and $100 \mu \mathrm{g}$ of protein. The mixture was preincubated 2 min at $37^{\circ} \mathrm{C}$ before adding $5 \mathrm{mM}$ of glycerol-3-phosphate (Sigma) as final concentration. The activity was recorded at $340 \mathrm{~nm}$.

\subsubsection{Glyceraldehyde 3-phosphate dehydrogenase:}

GAPDH activity was determined by monitoring NADH generation at $340 \mathrm{~nm}$ (Serrano, 1991). The reaction mixture of $1 \mathrm{ml}$ contained $50 \mathrm{mM}$ Tricine- $\mathrm{NaOH}$ buffer $\mathrm{pH} 8.5,10 \mathrm{mM}$ sodium arsenate, $1 \mathrm{mM} N A D+$ and 2 mM D-G-3-P.

\subsubsection{Succinate dehydrogenase:}

The enzyme was assayed according to King (1967) with assay conditions: $100 \mathrm{mM}$ potassium phosphate buffer (pH 7.4), $0.3 \mathrm{mM}$ EDTA, $0.053 \mathrm{mM} \mathrm{DCIP}$ and $100 \mu \mathrm{g}$ of protein. The mixture was preincubated $10 \mathrm{~min}$ at $37^{\circ} \mathrm{C}$ before adding $50 \mu \mathrm{l}$ of $\mathrm{KCN}$-Succinate (containing $3.25 \mathrm{mg} / \mathrm{ml}$ of $\mathrm{KCN}$ in $0.5 \mathrm{M}$ succinate). The measure of activity was done at $625 \mathrm{~nm}$. 


\subsubsection{Acetylcholinesterase:}

Assay procedure was assessed according to Ellman et al. (1961). The assay mixture of brain homogenate contained $80 \mathrm{mM}$ DTNB, $45 \mathrm{mM}$ acetylthiocholine and $100 \mathrm{mM}$ potassium phosphate buffer (pH 7.4). The absorbance at $412 \mathrm{~nm}$ was monitored.

\subsubsection{D-3-hydroxybutyrate dehydrogenase:}

BDH activity was measured as described by Lehninger (1960) following NADH production at 340 $\mathrm{nm}\left(\varepsilon=6.22 \times 10^{3} \mathrm{M}^{-1} \cdot \mathrm{cm}^{-1}\right)$ using $100 \mu \mathrm{g}$ of proteins from frozen mitochondria in a medium containing: $6 \mathrm{mM}$ potassium phosphate $\mathrm{pH} 8,0.5 \mathrm{mM}$ EDTA, 1.27\% (v/v) redistilled ethanol, 0.3 $\mathrm{mM}$ dithiothreitol, in the presence of $2 \mathrm{mM} \mathrm{NAD}+($ Sigma) and $2.5 \mu \mathrm{g}$ rotenone (final addition) to prevent NADH reoxidation by the respiratory chain. The activity was started by the addition of DL3-hydroxybutyrate (Sigma) to $10 \mathrm{mM}$ final concentration.

\subsubsection{In vitro $\mathrm{BDH}$ inhibition by 2,4D:}

For the determination of $2,4 \mathrm{D}$ concentration giving $50 \%$ inhibition $\left(\mathrm{IC}_{50}\right)$ of $\mathrm{BDH}$, the activities were measured as described previously in the absence and the presence of different 2,4D concentrations after preincubation for 5 minutes. For study of time course of inhibition, $100 \mu \mathrm{g}$ of thawed liver mitochondria protein were preincubated for 5 minutes at $25{ }^{\circ} \mathrm{C}$ in the buffered medium $(6 \mathrm{mM}$ potassium phosphate $\mathrm{pH} 8,0.5 \mathrm{mM}$ EDTA, $1.27 \%$ (v/v) redistilled ethanol). The 2,4D was added at zero time of incubation. Aliquots were removed at different times during the incubation for the enzymatic activity measurement. Aliquots of the control assay were removed at the same time in order to calculate the percentage of BDH activity.

\subsubsection{BDH kinetic studies:}

Initial velocities of the enzymatic reaction (in the presence of $2,4 \mathrm{D}$ at $0,1.66,3.33$ or $5 \mathrm{mM}$ ) were performed by varying the concentration of the substrates, $\mathrm{BOH}$ (from 2.5 to $10 \mathrm{mM}$ ) or NAD+ (from 0.5 to $2 \mathrm{mM})$. Values of the Michaelis constants $(\mathrm{Km})$, dissociation constants $\left(\mathrm{K}_{\mathrm{D}}\right)$ and maximal 
velocity for the oxidation of $\mathrm{BOH}$ and the reduction of $\mathrm{NAD}+$ by the $\mathrm{BDH}$ were obtained by mathematical analysis according to the method of Cleland (1963).

\subsubsection{BDH chemical protection:}

Two chemical protectors were used in this study: N-Ethylmaleimide (NEM) (Sigma) and Phenylglyoxal (PGO) (Aldrich-chemie) which are known to react specifically with cysteyl (Latruffe et al., 1980) and arginyl residues (El Kebbaj et al., 1980) respectively. $100 \mu \mathrm{g}$ of thawed liver mitochondria protein were preincubated for 5 minutes at $25{ }^{\circ} \mathrm{C}$ in the buffered medium $(6 \mathrm{mM}$ potassium phosphate $\mathrm{pH} 8,0.5 \mathrm{mM}$ EDTA, $1.27 \%(\mathrm{v} / \mathrm{v})$ redistilled ethanol) in the presence of $5 \mu \mathrm{M}$ NEM or $10 \mu \mathrm{M}$ PGO. The 2,4D ( $\left.\mathrm{IC}_{50}\right)$ was added and the enzymatic activity was measured as described previously. For all experiments, aliquots of the control assay were removed at the same time in order to calculate the percentage of BDH activity.

\subsubsection{Western-blotting:}

After SDS-PAGE (12\%) (Laemmli, 1970) and subsequent transfer in nitrocellulose (Towbin et al., 1992), the proteins from frozen mitochondria $(50 \mu \mathrm{g})$ were exposed to $1 / 100$ dilution of monospecific rabbit polyclonal anti-BDH anti-rat antibody and detected with the secondary antibody of anti-rabbit, IgG peroxidase conjugate (diluted to 1/2500) (Promega).

\subsubsection{Protein assay:}

Protein content was measured according to the Bradford procedure, using bovine serum albumin (BSA) as standard (Bradford, 1976).

\subsection{Histological analysis}

The jerboas were decapitated and the liver, brain and testicular glands were removed, fixed in Bouin liquid and embedded in paraffin according to Cau and Seite (1996). $4 \mu \mathrm{m}$ sections were stained with hematein-eosin, then examinated under light microscopy (Olympus-BH-2). 


\subsection{Immunofluorescence labeling}

$4 \mu \mathrm{m}$ sections were rinsed with PBS, and then blocked with $1 \%$ bovine serum albumin (BSA) in PBS (1\% BSA-PBS). Sections were then incubated in the primary antibody $(1 / 100)$ at room temperature for 1h, washed for 5 min with three changes of PBS, and incubated in the fluorescence-labeled secondary antibody solution (Sigma) 1/100 for $1 \mathrm{hr}$. Sections were then washed for 5 min with three changes of PBS. Fluorescence-stained sections were examined under an epifluorescence microscope (Olympus).

\subsection{Statistical data analysis:}

In each assay, the experimental data represent the mean of four independent assays \pm standards deviations. Means were compared using the Student t-test. Differences were considered significant at the level $\mathrm{p}<0.05$ and very significant at the level $\mathrm{p}<0.01$. The calculation of the inhibition concentrations (IC) is carried out by the analysis of probit (Bliss, 1935). 


\section{Results:}

\subsection{Effect of 2,4D on plasmatic parameters:}

The table I indicates that 2,4D strongly decreases triglycerides and HDL cholesterol levels $(-81.6 \%$ and $-30.2 \%$ respectively). In contrast, there is an increase in GOT level (183\%) and in LDL cholesterol (153\%). No changes were observed for glycemia, total cholesterol, GPT, CPK, urea and creatinine.

\subsection{In vivo effect of 2,4D on stress and metabolic biomarkers:}

For the stress biomarkers, the treatment of the jerboa shows that 2,4D induced a significant increase (24.1\%) in peroxidized lipid level (malondialdehyde-MDA) and a significant decrease in catalase activity (77.7\%) compared with the control (table II). Malondialdehyde (MDA) is a terminal product of lipid breakdown due to peroxidation damage and this (and other aldehydes) can be detected by its reaction with thiobarbituric acid. No changes were observed on superoxide dismutase and glutathione reductase activities.

For the metabolic markers, no changes were observed in the peroxisomal palmitoyl-CoA oxidase activity. Mitochondrial D-3-hydroxybutyrate dehydrogenase was very sensible to 2,4D; it strongly decreases $(64.3 \%)$. No changes were observed for mitochondrial succinate dehydrogenase.

Microsomal NADPH-cytochrome C reductase activity decreases significantly (46.1\%).

No changes were observed for cytosolic glycerol-3-phosphate dehydrogenase (G3PDH) and glyceraldehyde-3-phosphate dehydrogenase (GAPDH).

Brain acetylcholinesterase activity decreases significantly $(63.2 \%)$.

In order to explore the possible correlations between the various biomarkers, Principal Component Analysis (PCA) was carried out (figure 1). Principal Components Analysis is a way of identifying patterns in data, and expressing the data in a way that highlights their similarities and differences. The results show the existence of 2 principal groups: the first one which explained $62 \%$ of total variance, made up of the BDH, catalase, acetylcholinesterase and NADPH-Cytochrome C reductase. The second which explained $27.2 \%$ of total variance contains the G-3-PDH, GAPDH, palmitoyl- 
CoA oxidase and the MDA. All the components of the 1st group presented a significant reduction caused by the treatment by the $2,4 \mathrm{D}$, whereas the 2 nd group did not show any notable variation excepted for the MDA where the rate is increased.

\subsection{Morphological and histological study:}

The macroscopic analysis of the removed organs during the dissection revealed that the testes were more red and hypertrophied (an increase in 91\% of weight compared to controls) (figure 2A). Indeed, the testes weight of the control group of jerboa was $425 \mathrm{mg}( \pm 61)$ in comparison with the testes of the treated ones $(812 \mathrm{mg} \pm 112)$. All the other organs from treated animals have normal aspect and weight.

Optical microscopy of the testis from the 2,4D exposed jerboa shows a necrosis of the seminiferous tubules characterized by dissolution of the nucleus and nuclear membrane (karyolysis). Some cells showed hypertrophy or increase in individual cell size. Indeed, they showed moderate to complete pycnosis. This process in which cells undergo necrotic changes in the nuclei is characterized by rounding up and condensation resulting in hyperchromatic staining (pycnosis) (figure 2B).

In liver of the 2,4D exposed jerboa, we observed manifold centrilobular necrotic areas filled by detrits and connective tissue, hyperplasia of hepatocytes, as well as cytoplasmic dystrophy characterized by small vacuoles tightly packed in the cytoplasm. Additionally, sharply dilated central veins were noted (figure $3 \mathrm{~A}$ ).

In brain of the 2,4D exposed jerboa, there is an increase in the number of the nucleus as well as a hypercondensation of the chromatin. Also, we observed the presence of some multinucleated giant cells (figure 3B).

\subsection{In vivo impact of 2,4D on BDH activity :}

In order to know if the differences observed concerning BDH activities (see table II), were due to $\mathrm{BDH}$ variations level, western-blotting was carried out (Figure 4A). Its analysis revealed no changes of the $\mathrm{BDH}$ band. Also, the immunodetection of $\mathrm{BDH}$ by fluorescence in liver sections reveals no changes on BDH expression with jerboa control and treated groups (figure 4B). 
This suggests that the $\mathrm{BDH}$ inhibition observed in table II is not caused by BDH gene expression inhibition but due to a BDH catalytic inhibition by 2,4D.

\subsection{BDH inhibitory concentration:}

The figure 5 indicates that mitochondrial $\mathrm{BDH}$ was sensitive to the presence of 2,4D and this sensitivity depends on the concentration used. Indeed, the calculation of the inhibition concentrations of $50 \%$ of $\mathrm{BDH}$ activity $\left(\mathrm{IC}_{50}\right)$ by the analysis of probit (Bliss, 1935) reveals that $\mathrm{IC}_{50}$ was estimated at $6.69 \mathrm{mM} \pm 0.41$.

The time course of BDH inhibition by 2,4D was reported in figure 6 . The results show that BDH is rapidly and strongly inhibited by $2,4 \mathrm{D}$. We observed a complete inhibition after 35 minutes in the presence of $3 \mathrm{mM}$ of 2,4D (data not shown). The plots of log half time inactivation vs. $\log 2,4 \mathrm{D}$ concentration result in a straight line with a slope of 1.17 , indicating that the reaction is first order with respect to inhibitor concentration and that one mole of 2,4D per mole of enzyme is sufficient to produce inactivation (data not shown). The second order rate constant was also calculated to be 20 $\min ^{-1} \mathrm{M}^{-1}$ (data not shown).

\subsection{Effect of 2,4D on BDH kinetic parameters :}

The effects in vitro of 2,4D on BDH kinetic parameters were studied. Apparent BDH kinetic

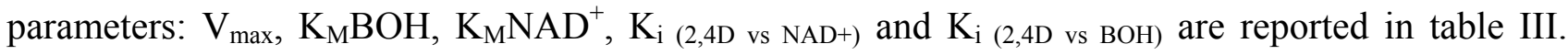
Interestingly, they show that the apparent kinetic constants with respect to the $\mathrm{NAD}^{+}$and $\mathrm{BOH}$ are modified when $\mathrm{BDH}$ is exposed to 2,4D: $\mathrm{K}_{\mathrm{M} N A{ }^{+}}$and $\mathrm{K}_{\mathrm{M}} \mathrm{BOH}$ were increased (x 11.61 and $\mathrm{x} 2.46$ respectively). Also, $\mathrm{K}_{\mathrm{i}(2,4 \mathrm{D} \text { vs } \mathrm{NAD+})}$ and $\mathrm{K}_{\mathrm{i}(2,4 \mathrm{D} \text { vs } \mathrm{BOH})}$ calculed were $3.38 \mathrm{mM}$ and $5.74 \mathrm{mM}$ respectively.

\subsection{BDH protection to 2,4D :}

The NEM and PGO react specifically with cysteyl and arginyl residues respectively. The choice of their modificators was due to the presence of the cysteyl and arginyl in the active site of BDH (Latruffe et al., 1980, El Kebbaj et al., 1980). 
Figure 7 shows that the fixation of the NEM on BDH caused $34 \%$ of inhibition while when we added 2,4D, the inhibition increased to $73 \%$. This increase can be due to the fixation of 2,4D on other amino acid residue leading to a local conformational change.

Figure 7 shows also that the fixation of the PGO on BDH caused $59 \%$ of inhibition. The addition of $2,4 \mathrm{D}$, doesn't change the degree of inhibition (62\%). There results are in agreement with the fixation of 2,4D at arginyl residue(s) of the $\mathrm{BDH}$ active site and not at cysteyl one(s).

\section{Discussion:}

Pesticides are worldwide used in agriculture each year in vast amounts and herbicides are the most prominent class. Phenoxyacetic herbicides constitute one of the largest groups of herbicides sold in the world. Among them, for many years 2, 4-dichlorophenoxyacetic acid $(2,4 \mathrm{D})$ has been the largely used. In this study we used 2,4D to determine its possible toxic effects on jerboa (Jaculus orientalis). Previously, we have reported that jerboa (Jaculus orientalis) shows unique peroxisome properties and responds in a moderate manner to peroxisome proliferators, without leading to any increase in liver mass or hepatomegaly in contrast with rat, guinea pig and human (El Kebbaj et al., 1996).

We focused our study on pesticide formulation instead on purified active ingredient (A mon avis c'est l'inverse, nous avons utilisé du 2,4D purifié-> clarifier la suite) because workers producing and applying pesticides are exposed to such formulations and not only to active ingredients. There are many findings that pesticide formulations with 2, 4D contain by-product of its industrial synthesis as polychlorinated dibenzodioxins (PCDD) (Linnainmaa, 1983), nitrosamines (Ibrahim et al., 1991) and other chlorinated phenols that may express clastogenic activity (Gandhi et al., 1998; Ibrahim et al., 1991; Mustonen et al., 1986). Furthermore, beside active ingredient and its production by products pesticide formulations contain number adjuvants (solvents, dilutants, dispersants, emulgators, potentiators) that are kept secret by manufacturers and also might present risk for genomic stability. Therefore, in occupational exposure 
to pesticides, all those chemicals, not only active ingredients, affect human health, so all of them should be considered in cytogenetical research simulating the exposure. Some studies reveal that 2,4D lead to apoptosis of human lymphocytes (Kaioumova et al., 2001), HepG2 cells (Tuschl and Schwab, 2003), and cerebellar granule cells (De Moliner et al., 2002), and are associated with nonHodgkin's lymphoma and other cancers (McDuffie et al., 2001 ; Ibrahim et al., 1991 ; Bradberry et al., 2000).

Studies sponsored jointly by FAO and WHO (USDA, 1980) showed that 2,4D residues in the grain at harvest was around $0.36 \mathrm{mg} / \mathrm{kg}$ when good agricultural practice is followed. Nevertheless, it is estimated that the dietary exposure to $2,4 \mathrm{D}$ does not exceed $22 \%$ of a chronic population adjusted dose (cPAD) for the general population. cPAD represents the dose at which an individual could be exposed over the course of a lifetime and no adverse health effects would be expected, and for 2,4D it appears to be $0,013 \mathrm{mg} / \mathrm{kg} /$ day. To get the total estimated exposure of the general population to $2,4 \mathrm{D}$, which is assumed to be up to $0,006 \mathrm{mg} / \mathrm{kg}$ per day besides dietary exposure, the pesticide intake calculated on the basis of estimated environmental concentrations (EEC) of 2,4D in surface water (15 ppb) and ground water (14.8 ppb), as well as residential risk assessment should be taken into account (EPA, 2002). However, it is known that the occupational exposures to chemicals are up to 1000 times higher than those for the general population. The intake of $2,4 \mathrm{D}$, due to occupational exposure during its production and application, was estimated to be $0,1-0,4 \mathrm{mg} / \mathrm{kg}$ per day when all protective measures are taken, which is often not the case (WHO, 1984).

On the other hand, the oral LD50 of 2, 4D in rats ranges from 375 to $666 \mathrm{mg} / \mathrm{kg}$ and dermal LD50 has a value of $1500 \mathrm{mg} / \mathrm{kg}$.

In our study, we used a dose of $3 \mathrm{mg} / \mathrm{kg} /$ day which widely lowers than doses applied to the rodents and so a little superior to that of cPAD.

Also, in order to all the dose passes in the blood circulation of the jerboa, we think that most simple method of administration was the intraperitoneal way. 
In jerboa, the in vivo 2,4D treatment causes an important decrease in HDL and triglycerides levels and an increase in LDL and GOT ones (table I). These results suggest a perturbation of lipid metabolism in jerboa which can develop atherosclerosis and cardiac pathologies after long time. The impact of 2,4D on the liver function was also evaluated by the assays of metabolic enzymes and of stress biomarkers (table II). The results show a moderated oxidative stress in liver cells caused by the 2,4D. This stress is shown on lipidic peroxidation (MDA).

Importantly, we found that $2,4 \mathrm{D}$ causes the testis hypertrophy in jerboas (figure 2A). Previous studies show that 2,4D has a genotoxic effect both in the somatic and germ-line cells of Drosophila (Tripathy, 1993). Others studies show an important decrease in foetal body weights and increased foetal variations in rats exposed to 2,4D (Jeffrey et al., 2001). Also, Alavanja et al. (2003) demonstrated in human the existence of a significantly association between pesticides such as $2,4 \mathrm{D}$ and prostate cancer risk.

Also, the analysis of the histological sections of liver and brain shows cells necrosis for the liver and the beginning of tumor development for the brain. Liver cells necrosis can cause the migration of immunizing cells and the expansion of blood vessels which improve the development of the inflammatory reactions. Moreover, acetylcholinesterase activity in brain decreases significantly. Indeed, 2,4D is one of few herbicides to cause nervous system damage which includes inflamed nerve endings, lack of coordination, stiffness in the arms and legs, inability to walk, fatigue, stupor, coma, and death (Zahm, 1990).

In dogs, large doses of 2,4D (100 mg/kg of body weight) cause anorexia, inability to stand, and death (Hayes and Howard, 1991). Similar clinical signs were found in rabbits and rats; $50 \mathrm{mg} / \mathrm{kg}$ of 2,4D cause ataxia, muscular stiffness, decreased motor activity and mortality (Jeffrey et al., 2001).

Moreover, 2,4D exposure has been linked to an increased risk of cancer. A study by the National Cancer Institute found that dogs with lymphoma were more likely than healthy dogs to have owners who treated their lawns with 2,4D (or contracted with lawn care companies). The increased risk of lymphoma doubled for lawns that were treated four times per year (Drill, 1953; Hayes and Howard, 
1991). In human, the dermal absorption of $2,4 \mathrm{D}$ was proved and can present an important risk to human heath (John et al., 2005).

In order to study the impact of the $2,4 \mathrm{D}$ on mitochondria, we choose $\mathrm{BDH}$ as marker of the redox balance. The results showed an important in vivo decrease in the BDH activity (table II). Similar results were obtained in rat and protozoa (Tetrahymena pyriformis) (Cherkaoui Malki et al., 1991; El Kebbaj et al., 1995) by using 2,4D and other hypolipemic agents (clofibrate, ciprofibrate and clobuzarit). This decrease is not caused by a modification in BDH expression (figures 6 and 7) but by the inhibitory effect of 2,4D by fixation on $\mathrm{BDH}$ active site (figures 5, 6 and table III).

Chemical modification of essential aminoacids residues by specific derivating agents is a well known method to identify the active site aminoacids composition by estimation of the rate of enzyme inactivation and to demonstrate the enzyme conformational change. In our study we used the NEM (specific to cysteine) and the PGO (specific to the arginine) since studies already published by our laboratory showed that the $\mathrm{BDH}$ active site contains one essential cysteine and one essential arginine for BDH activity (El Kebbaj et al., 1980, Latruffe et al., 1980). The aim was to know the aminoacid implicated in the fixation of 2,4D at the $\mathrm{BDH}$ active site. The results obtained reveal that this fixation is done on the arginyl residues (figure 7). Such effect can lead changes in the $\mathrm{NAD}+\mathrm{NADH}$ equilibrium through the ketone bodies interconversion and consequently affect the physiological functions of cells.

\section{Conclusion:}

The present study showed the toxicity of 2,4D which induces karyolysis, hypertrophy, necrosis and oxidative stress. Moreover, the D-3-hydroxybutyrate dehydrogenase (mitochondrial marker) is inhibited after in vivo and in vitro 2,4D treatment. This inhibition was done at the BDH active site especially at its arginyl residues. Since this enzyme is involved in the ketone bodies interconversion and these compounds play a role in the energy metabolism of extrahepatic tissues, 2,4D can cause perturbation on energetic metabolism. So, the use of herbicides in agricultural fields induces health 
problems due to environmental persistence and an increase in concentration during the passage through the food chain. Food is the major route for exposure of human population to the toxic chemicals. The assessment of possible risk to species in the natural environments and the determination of water quality criteria are urgently needed.

\section{ACKNOWLEDGEMENTS}

This work was supported by the Regional Council of Burgundy and IFR $n^{\circ} .92$, and by the «Programme Thématique d'Appui à la Recherche Scientifique-Morocco, Biologie no.134 », and by the « Action intégrée franco-marocaine MA/05/134 ».

\section{References:}

Aebi, H. (1984) Catalase in vivo. Meth. Enzymol. 105:121-126.

Alavanja, M., Samanic, C., Dosemeci, M., Lubin, J., Tarone, R., Lynch, C.F., Knott, C., Thomas, K., Hoppin, J.A., Barker, J., Coble, J., Sandler, D.P., Blair, A. (2003) Use of Agricultural Pesticides and Prostate Cancer Risk in the Agricultural Health Study Cohort. American Journal of Epidemiology, 157: $800-814$.

Amsaguine-Safir, S., Bianchi, A., Collet, P., Huin-Schohn, C., Jeanvoine, A., Becuwe, P., KremarikBouillaud, P., Domenjoud, L., Keller, J.M., Schohn, H., Dauca, M. (2003) Induction of the expression of the peroxisome proliferator-activated receptor alpha (PPARalpha) by clofibrate in jerboa tissues. Microsc. Res. Tech. 61:185-90.

Argese, E., Bettiol, C., Marchetto, D., De Vettori, S., Zambon, A., Miana, P., Ghetti, P.F. (2005) Study on the toxicity of phenolic and phenoxy herbicides using the submitochondrial particle assay. Toxicology in Vitro 19: 1035-104 
Associate committee on Scientific Criteria for Environmental Quality; Subcommittee on Pesticides and Industrial Organic Chemicals (1994) 2,4-D Some Current Issues. NRCC 20647. National Research Council of Canada, p.23.

Bentley, P., Dickinson, F.M., Jones, I.G. (1973). Purification and properties of rabbit muscle $\alpha$ glycerophosphate dehydrogenase. Biochem. J., 135: 853-859.

Bliss, C.I. (1935) The calculation of the dosage mortality curve. Ann. Appl. Biol. 22: 134-165.

Bradberry, S.M., Watt, B.E., Proudfoot, A.T., Vale, J.A. (2000) Mechanisms of toxicity, clinical features and management of acute chlorophenoxy herbicide poisoning: a review, Clin. Toxicol. 38 $111-122$.

Bradford, M. (1976) A rapid and sensitive method for the quantization of microgram quantities of protein utilizing the principle of protein dye binding, Anal. Biochem., 72: 248-254.

Cau, P., Seite, R., (1996). Cours de biologie cellulaire. Edit ellipses-Paris. 73.

Cherkaoui Malki, M., Assaka, L., Pacot, C., Bardot, O., Latruffe, N., (1991) Effect of different hypolipemic agents on rat liver peroxisomal and mitochondrial functions and biogenesis. Cell. Mol. Biol. 37: 723-733.

Cleland, W.W. (1963) The Kinetics of enzymes catalysed reaction with two or more substrates or products, Nomenclature and rate equations, Biochim. Biophys. Acta 67: 104-137.

De Moliner, K.L., Evangelistade Duffard, A.M., Soto, E., Duffard, R., Adamo, A.M. (2002) Induction of apoptosis in cerebellar granule cells by 2, 4-dichlorophenoxyacetic acid, Neurochem. Res. 27 $1439-1446$.

Di Ilio, C., Polidoro, G., Arduini, A., Muccini, A., Federici, G., (1983) Glutathione peroxidase, Glutathione reductase, gluthatione S-transferase and gamma_glutamyl transpeptidase activities in the human early pregnancy placenta. Biochem. Med., 29: 143-148.

Drill, V.A., Hiratzka, T. (1953) Toxicity of 2,4-dichlorophenoxyacetic acid and 2,4,5trichlorophenoxyacetic acid. Ind. Hyg. Occup. Med. 7: 61-67.

El Hilali, M., Veillat, J.P., (1979) Jaculus orientalis: A true Hibernator, Mammalia 39: 401-404. 
El Kebbaj, M.S., Latruffe, N., Gaudemer, Y. (1980) Presence of an essentiel Arginyl residue in D-3hydroxybutyrate dehydrogenase from mitochondrial inner membrane, Biochem. Biophys. Res. Commun. 96: 1569-1578.

El Kebbaj, M.S., Cherkaoui Malki, M., Latruffe, N., (1995) Effect of peroxisomes proliferators and hypolipemic agents on mitochondrial inner membrane linked D-3-hydroxybutyrate dehydrogenase (BDH).Biochem. Mol. Biol. Intern. 35: 65-77.

El Kebbaj, M.S., Cherkaoui Malki, M., Latruffe, N. (1996) Properties of peroxisomes from jerboa (Jaculus orientalis). Eur J Cell. Biol. 70: 150-6.

El Kebbaj, M.S., Latruffe, N. (1997) Alkylation at the active site of the of D-3-hydroxybutyrate dehydrogenase a membrane phospholipid-dependent enzyme, by $\beta$-chloroacetyl pyridine adenine dinucleotide (3-CAPAD), Biochimie 79: 37-42.

Ellman, G.L., Courtney, K.D., Andreas, V., Featherstone, R.M., (1961) A new and rapid colorimetric determination of AChE activity. Biochem Pharmacol 7:88-95.

EPA, 2002. Federal Register 2,4D: Time-limited pesticide tolerance 46 (67).

Fleischer, S., Mc Intyre, J.O., Vidal, J.C. (1979) Large-scale preparation of liver mitochondria in high yield, Method. Enzymol, 55; 32-39 (Fleischer S. and Packer L., eds) Acad. Press. New York.

Hayes, M., Howard, M. (1991) Case-Control Study of Canine Malignant Lymphoma: Positive Association With Dog Owner's Use of 2,4-Dichlorophenoxyacetic Acid Herbicides. Journal of the National Cancer Institute. 83: 1226-1231.

Hooper, E.T., El Hilali, M. (1972) Temperature regulation and habits in two species of jerboa, genus Jaculus, J Mammal 53: 574-593.

Ibrahim, M.A., Bond, G.G., Burke, T.A., Cole, P., Dost, F.N., Enterline, P.E., Gough, M., Greenberg, R.S., Halperin, W.E., McDonnel, E. (1991) Weight of the evidence on the human carcinogenicity of 2,4-D, Environ. Health Perspect. 96 213-222. 
Jeffrey, M., Charles, Thomas, R., Hanley, Jr., Ronald, D., Wilson, Bernard, van Ravenzwaay, and James, S., Bus, (2001) Developmental toxicity studies in rats and rabbits on 2,4dichlorophenoxyacetic acid and its forms. Toxicology sciences, 60: 121-131.

John, H., Rossa, Jeffrey, H., Driverb, Shelley, A., Harrisc, Howard, I., Maibachd, (2005) Dermal absorption of 2,4D: a review of species differences. Regulatory Toxicology and Pharmacology, 41: $82-91$.

Kabine, M., El Kebbaj, Z., Oaxaca-Castillo, D., Clemencet, M.C., El Kebbaj, M.S., Latruffe, N., Cherkaoui-Malki, M. (2004) Peroxisome proliferator-activated receptors as regulators of lipid metabolism; tissue differential expression in adipose tissues during cold acclimatization and hibernation of jerboa (Jaculus orientalis). Biochimie. 86:763-70.

Kaioumova, D., Susal, C., Opelz, G. (2001) Induction of apoptosis in human lymphocytes by the herbicide 2, 4-dichlorophenoxyacetic acid, Hum. Immunol. 62: 64-67.

Kante, A., Malki, M.C., Coquard, C., Latruffe, N., (1990) Metabolic control of the expression of mitochondrial D- $\beta$-hydroxybutyrate dehydrogenase, a ketone body converting enzyme, Biochim. Biophys. Acta. 1033: 291-297.

King, T.E., (1967) Preparation of succinate cytochroine c reductase and cytochroine b-cl particles and reconstitution of succinate-cytochrorne c reductase, in: R. Estabrook (ed.) Meth. Enzymol., 10: 216225. Academic Press. Orlando, San Diego, New York, London, Toronto, Montreal, Sydney, Tokio.

Kogevinas, M. (1995) Soft Tissue Sarcoma and non-Hodgkins Lymponmain Workers exposed to phenoxy-herbicides, chlorophenols, and dioxins - 2 nested case studies. Epidemiology. 6: 396-402. Laemmli, U.K. (1970) Cleavage of structural proteins during the assembly of the head of bacteriophage T4, Nature 227: 4668-4673.

Latruffe, N., Brenner, S.C., Fleischer, S. (1980) Essential sulfhydryl for reduced nicotinamide adenine dinucleotide binding in D-3-hydroxybutyrate dehydrogenase, Biochemistry 19: 5285-5290.

Lazarow, P.B., De Duve, C., (1976) A fatty acyl-CoA oxidizing system in rat liver peroxisomes ; enhancement by clofibrate, a hypolipidemic drug, Proc. Natl. Acad. Sci. USA 73: 2043-2046. 
Lehninger, A.L., Sudduth, H.C., Wise, J.B. (1960) D-3-hydroxybutyric dehydrogenase of mitochondria, J. Biol. Chem., 235: 2450-2455.

McDuffie, H.H., Pahwa, P., McLaughlin, J.R., Spinelli, J.J., Fincham, S., Dosman, J.A., Robson, D., Skinnider, L.F., Choi, N.W. (2001) Non-Hodgkin_s lymphoma and specific pesticide exposures in men: cross-Canada study of pesticides and health, Cancer Epidemiol. Biomarkers Prev. 101155 1163.

Mountassif, D., Kabine, M., Latruffe, N., El Kebbaj, M.S. (2006) Characterization of two D-3hydroxybutyrate dehydrogenase populations in heavy and light mitochondria from jerboa (Jaculus orientalis) liver. Comp Biochem Physiol B Biochem Mol Biol. 143: 285-293.

Paoletti, F., Aldinucci, D., Mocali, A., Carparrini, A. (1986) A sensitive spectrophotometric method for the determination of superoxide dismutase in tissue extracts. Anal. Biochem., 154: 526-541.

Samokyszyn, V.M., Marnett, L.J. (1990) Inhibition of liver microsomal lipid peroxidation by 13-cisretinoic acid. Free Radic Biol Med., 8: 491-6.

Serrano, A., Mateos, M.I., Losada, M. (1991) Differential regulation by trophic conditions of phosphorylating and non-phosphorylating NADP+-dependent glyceraldehyde-3-phosphate dehydrogenases in Chlorella fusca, Biochem. Biophys. Res. Commun. 181: 1077-1083.

Towbin, H., Stahelin, T., Gordon, J. (1992) Electrophoretic transfer of proteins from polyacrylamide gels to nitrocel procedure and applications, Biotech. 24: 145-149.

Tripathy, N.K. (1993) Genotoxicity of 2,4-diclorophenoxyacetic acid tested in somatic and germ-line cells of Drosophila. Mut. Res. 319:237-242.

Tuschl, H., Schwab, C. (2003) Cytoxic effects of the herbicide 2,4-dichlorophenoxyacetic acid in HepG2 cells, Food Chem. Toxicol. 41: 385-393.

USDA, 1980. Submission from the United States Department of Agriculture to FAO: Pesticide residues in food (Evaluations, 1980).

Williams, C.H., Kamin, H. (1962) Microsomal triphosphopyridine nucleotide-cytochrome c reductase of liver. J. Biol. Chem., 237: 587-595. 
Williamson, D.H., Bates, H.N., Page, M.A., Krebs, H.A. (1971) Activities of enzymes involved in acetoacetate utilization in adult mammalian tissues, Biochem. J. 121: 41-47.

WHO, 1984. 2, 4-Dichlorophenoxiycetic acid (2,4D). In: Environmental Health criteria 29. World Healrh Organisasion, Geneva.

Zahm, S.H. (1990) A case control study of non-Hodgkin's lymphoma and the herbicide 2,4D in Eastern Nebraska. Epidemiology 1: 349-356.

Zeljezic, D., Garaj-Vrhovac, V. (2004) Chromosomal aberrations, micronuclei and nuclear buds induced in human lymphocytes by 2, 4-dichlorophenoxyacetic acid pesticide formulation. Toxicology 200 : $39-47$. 


\section{Tables \& Figures}

Table 1

Plasmatic parameters from control and 2,4D treated jerboa

\begin{tabular}{lcc}
\hline & Control & $2,4 \mathrm{D}$ \\
\hline Glycemia $(\mathrm{g} / \mathrm{l})$ & $1.25 \pm 0.12$ & $1.17 \pm 0.09$ \\
Total cholesterol $(\mathrm{mg} / \mathrm{l})$ & $1.11 \pm 0.22$ & $1.20 \pm 0.25$ \\
Triglycerides $(\mathrm{mg} / \mathrm{l})$ & $1.44 \pm 0.46$ & $0.265^{*} \pm 0.049(-80 \%)$ \\
HDL cholesterol $(\mathrm{mg} / \mathrm{l})$ & $0.745 \pm 0.063$ & $0.52^{*} \pm 0.056(-30 \%)$ \\
LDL cholesterol $(\mathrm{mg} / \mathrm{l})$ & $0.185 \pm 0.077$ & $0.525^{*} \pm 0.049(\times 2.83)$ \\
GOT $(\mathrm{U} / \mathrm{l})$ & $159 \pm 5.65$ & $403.5^{*} \pm 91.2(\times 2.53)$ \\
GPT $(\mathrm{U} / \mathrm{l})$ & $6 \pm 2.24$ & $5.5 \pm 2.21$ \\
CPK $(\mathrm{U} / \mathrm{l})$ & $1143 \pm 280$ & $840.5 \pm 410.8$ \\
Urea $(\mathrm{g} / \mathrm{l})$ & $0.38 \pm 0.08$ & $0.34 \pm 0.11$ \\
Creatinine $(\mathrm{mg} / \mathrm{l})$ & $6.5 \pm 0.07$ & $7.1 \pm 0.05$ \\
\hline
\end{tabular}

Values are given as means of four separated animals \pm standards deviations. " $p<0.05 ;{ }^{* *} p<0.01$ (Student's $t$-test).

Table 2

Effect in vivo of 2,4D on response of oxidative stress and metabolic biomarkers

\begin{tabular}{|c|c|c|}
\hline & Control & $2,4 \mathrm{D}$ \\
\hline Superoxide dismutase ( $\mu \mathrm{mol} / \mathrm{min} / \mathrm{mg}$ of protein) & $5.54 \pm 1.04$ & $3.79 \pm 1.47$ \\
\hline Gluthation reductase ( $\mathrm{nmol} / \mathrm{min} / \mathrm{mg}$ of protein) & $6.95 \pm 0.47$ & $5.35 \pm 1.03$ \\
\hline Thiobarbutiric acid reactive substances (nmol/mg of protein) & $0.29 \pm 0.02$ & $0.36 \pm 0.02^{*}(+24.1 \%)$ \\
\hline Catalase ( $\mu \mathrm{mol} / \mathrm{min} / \mathrm{mg}$ of protein) & $0.162 \pm 0.04$ & $0.058 \pm 0.016^{*}(-77.7 \%)$ \\
\hline Palmitoyl-CoA oxidase ( $\mathrm{nmol} / \mathrm{min} / \mathrm{mg}$ of protein) & $8.4 \pm 2.4$ & $14 \pm 4.6$ \\
\hline$\beta$-Hydroxybutyrate dehydrogenase ( $\mathrm{nmol} / \mathrm{min} / \mathrm{mg}$ of protein) & $0.21 \pm 0.012$ & $0.075 \pm 0.03^{* *}(-64.3 \%)$ \\
\hline Succinate dehydrogenase (absorbance/min/mg of protein) & $3.08 \pm 0.43$ & $2.70 \pm 0.73$ \\
\hline NADPH-cytochrome $C$ reductase (nmol $/ \mathrm{min} / \mathrm{mg}$ of protein) & $104 \pm 20$ & $56 \pm 9.2 *(-46.1 \%)$ \\
\hline Acetylcholinesterase ( $\mathrm{nmol} / \mathrm{min} / \mathrm{mg}$ of protein) & $81.32 \pm 19.27$ & $29.91 \pm 6.3^{*}(-63.2 \%)$ \\
\hline Glycerol-3-phosphate dehydrogenase (nmol/min/mg of protein) & $1.13 \pm 0.09$ & $1.24 \pm 0.05$ \\
\hline Glyceraldehyde-3-phosphate dehydrogenase $(\mu \mathrm{mol} / \mathrm{min} / \mathrm{mg}$ of protein) & $0.53 \pm 0.12$ & $0.6 \pm 0.09$ \\
\hline
\end{tabular}

Values are given as means of four separated animals \pm standards deviations. For experimental conditions, see Section $2 .{ }^{*} p<0.05 ;{ }^{* *} p<0.01$ (Student's $t$-test).

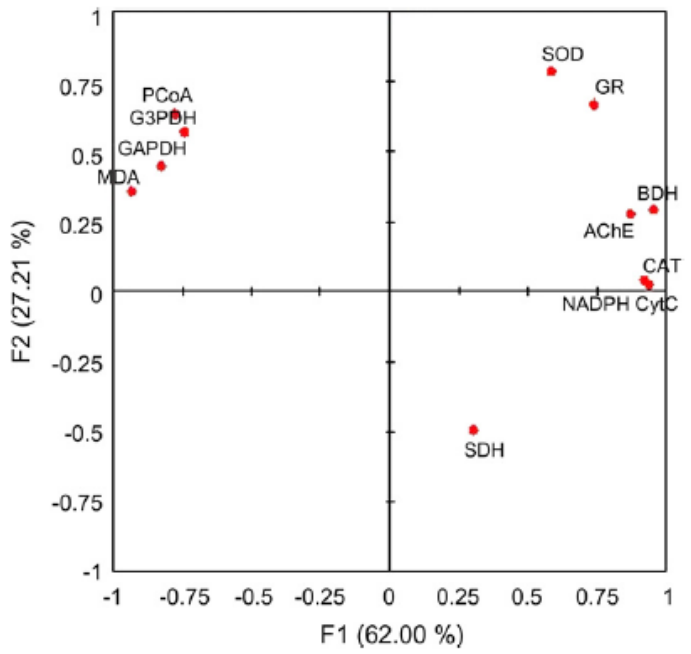

Fig. 1. Principal component analysis including all studied parameters. 


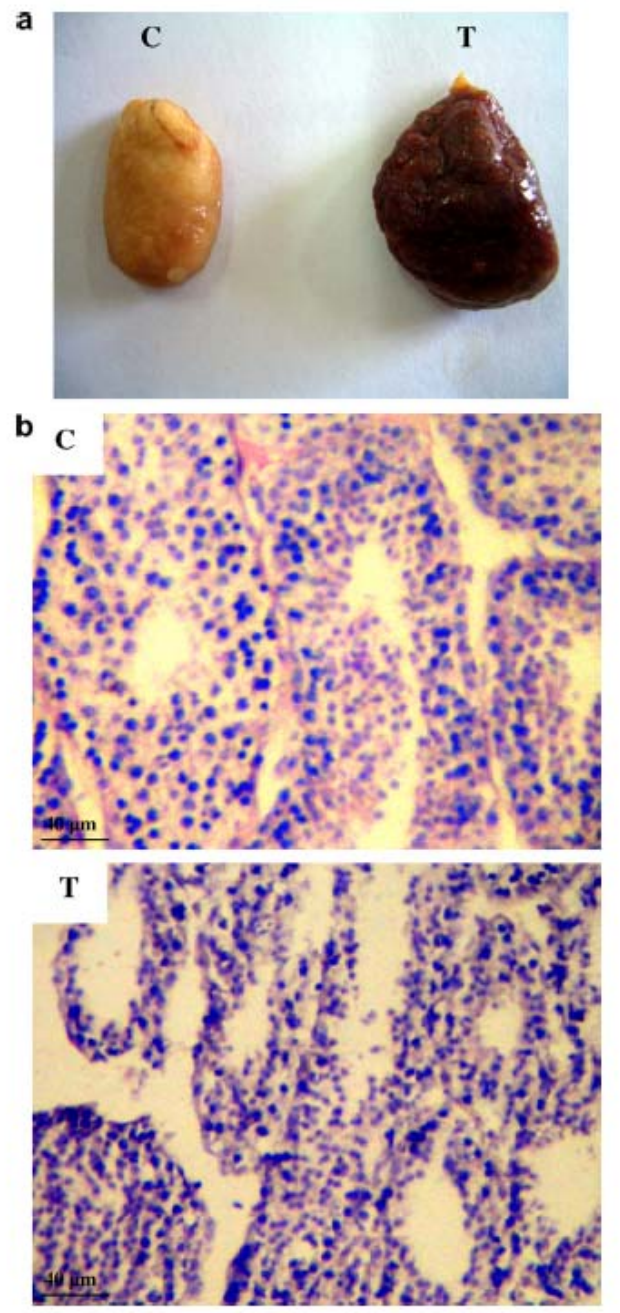

Fig. 2. V iew of testis organs (a) (magnification: $1 \times$ ) and its histological ections (b) from control (c) and 2,4D treated ( $\mathrm{T}$ ) typical jerboa. Sections were stained with hematein-eosin (magnification: $400 \times$ ).
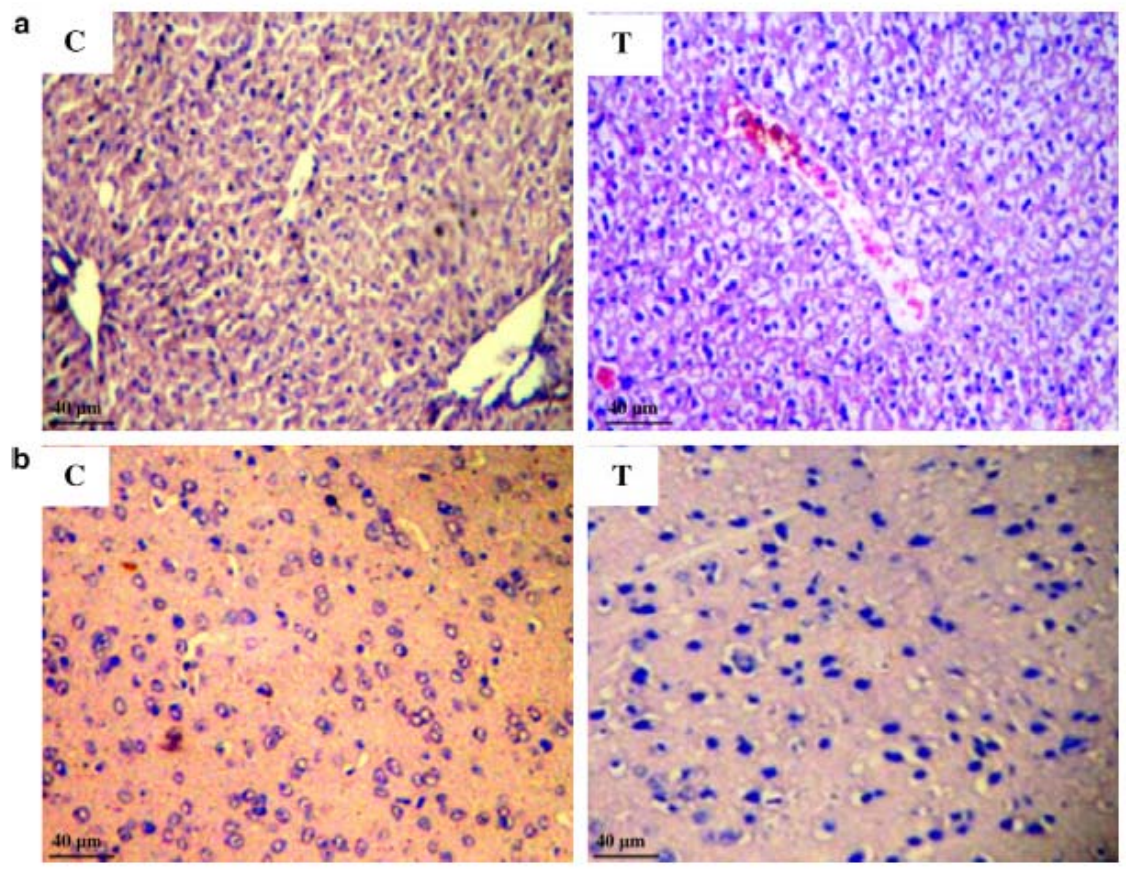

Fig. 3. Histological sections of liver (a) and brain (b) from control (c) and 2,4D treated (T) typical jerboa. Sections were stained with hematein-eosin magnification: $400 x$ ) 
a

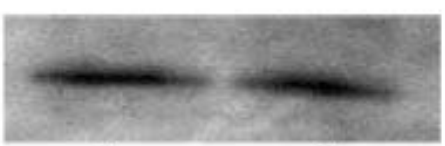

C $\mathbf{T}$

b
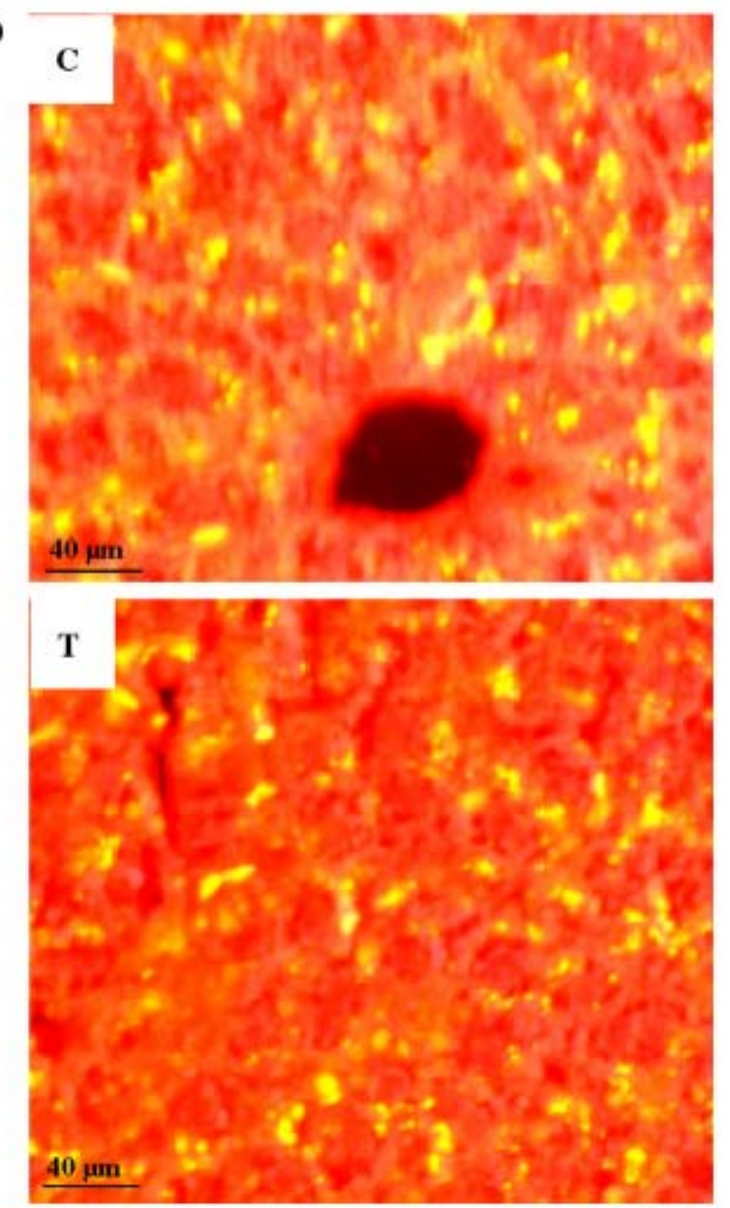

Fig. 4. (a) Western blot of the BDH from control and 2,4D treated jerboa liver. SDS-PAGE was assayed with $50 \mu \mathrm{g}$ of proteins from frozen mitochondria. (c and T) Mitochondria extracts from control and 2,4D treated individual jerboas, respectively. (b) Immunofluorescence labeling and subsequent microscopy of BDH of control (a) and treated (b) jerboa liver. Evans blue was used as against dye, and appears in red. BDH labeling appears in yellow. For experimental conditions, see Section 2. (For interpretation of the references to colour in this figure legend, the reader is referred to the web version of this article.) 


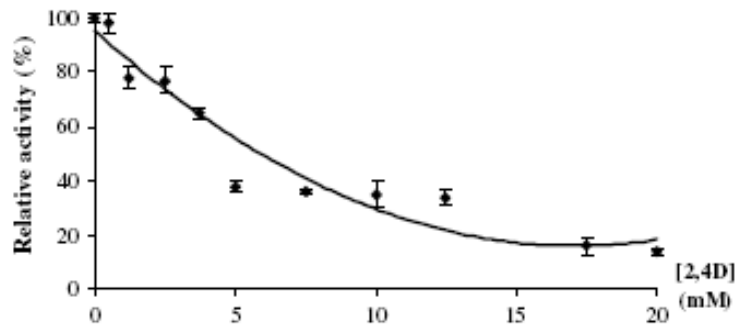

Fig. 5. In tritro effect of $2,4 \mathrm{D}$ concentration on $\mathrm{BDH}$ activity. Values are given as means of four control jerboas. For experimental conditions, see Section 2.

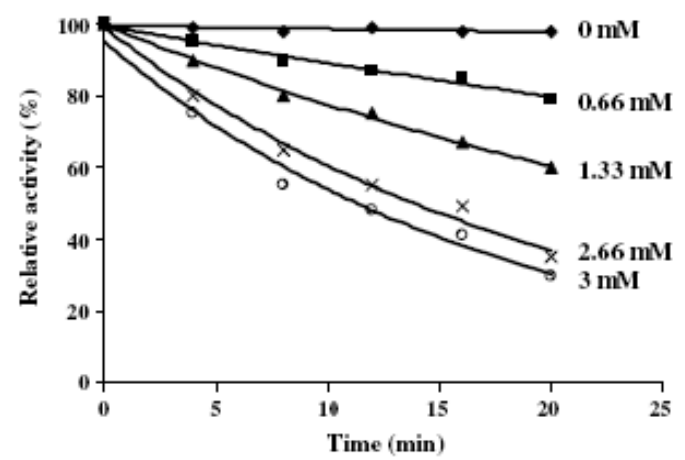

Fig. 6. Inactivation time course of $\mathrm{BDH}$ by various concentrations of 2,4D (semi log plot). Values are given as means of four control jerboas. For experimental conditions, see Section 2.

Table 3

Determination of the apparent kinetic parameters of the liver BDH (frozen mitochondrial fractions from control jerboa) in presence and absence of $2,4 \mathrm{D}$

\begin{tabular}{lcl}
\hline & Control & $2,4 \mathrm{D}$ \\
\hline$K_{\mathrm{M}} \mathrm{NAD}^{+}(\mathrm{mM})$ & $0.21 \pm 0.01$ & $2.44 \pm 0.76^{*}(\times 11.61)$ \\
$K_{\mathrm{i} 2,4 \mathrm{D} \text { w NAD }}(\mathrm{mM})$ & None & $3.38 \pm 0.6$ \\
$K_{\mathrm{M}} \mathrm{BOH}(\mathrm{mM})$ & $1.6 \pm 0.22$ & $3.94 \pm 0.6^{*}(\times 2.46)$ \\
$K_{\mathrm{i} 2,4 \mathrm{D} \text { w BOH }}(\mathrm{mM})$ & None & $5.74 \pm 0.7$ \\
$V_{\max }(\mathrm{nmol} / \mathrm{min} / \mathrm{mg}$ of protein) & $0.44 \pm 0.04$ & $0.32 \pm 0.02$ \\
\hline
\end{tabular}

Experiments were varying $\mathrm{NAD}^{+}$concentration $(0.5 ; 1 ; 1.5$ and $2 \mathrm{mM})$ or $\mathrm{BOH}$ concentration $(2.5 ; 5 ; 7.5$ and $10 \mathrm{mM})$ and $2,4 \mathrm{D}$ concentration $(0 ;$ $1.66 ; 3.33$ and $5 \mathrm{mM})$. Values are given as means \pm standard deviations from four different animals. " $p<0.01$ (Student's $t$-test).

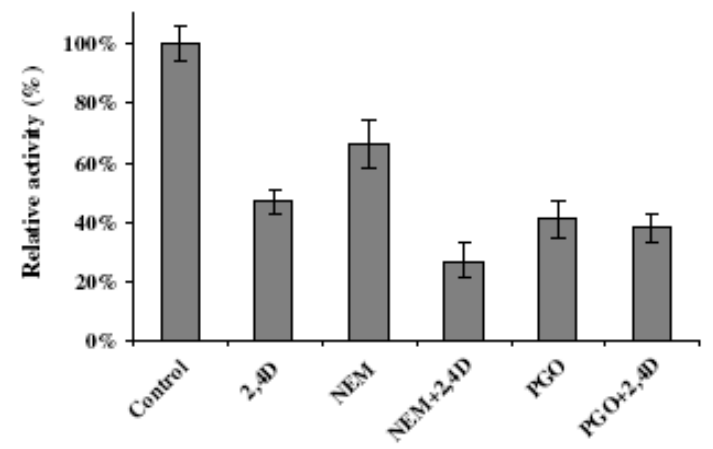

Fig. 7. Protection of $\mathrm{BDH}$ against $2,4 \mathrm{D}$. Values are given as means of four control jerboas. For experimental conditions, see Section 2. 